\title{
GADAMER E DUSSEL: DA HERMENÊUTICA DO DIÁLOGO IMPESSOAL AO DIÁLOGO QUE LIBERTA O ROSTO DA MÁSCARA COLONIAL
}

\author{
RENATO CARVALHO DE OLIVEIRA ${ }^{1}$
}

\begin{abstract}
RESUMO: O presente artigo trata do diálogo. A tese é que a hermenêutica de Gadamer não serve para a filosofia da libertação pensar o diálogo na América Latina, devido ao contraste metafísico de ambas. $\mathrm{O}$ autor alemão dedicou-se ao tema e propôs uma hermenêutica do diálogo para a filosofia ocidental. Dialogar é uma relação de conhecimento com o tu impessoal de textos do passado (tradição), o qual é um vestígio metafísico de que o fundamento do diálogo, da hermenêutica de Gadamer, não é o mesmo da filosofia latino-americana. Portanto, o objetivo desta pesquisa é revisar a concepção de diálogo, desde o aporte crítico da filosofia de Enrique Dussel. A metodologia se divide em duas partes. A primeira é uma crítica do diálogo na hermenêutica de Gadamer. A segunda trata da perspectiva de diálogo inferida das reflexões de Dussel sobre o conceito de consciência ética. A conclusão é que enquanto a hermenêutica alemã propõe um diálogo com base no tu impessoal da tradição, a filosofia da libertação sugere um diálogo cujo fundamento é o rosto de carne transformado em máscara pela colonialidade eurocêntrica do poder, do saber e do Ser. A implicação ética é que dialogar significa libertar a alteridade latino-americana.
\end{abstract}

PALAVRAS-CHAVE: Diálogo; Ser; Libertação; Alteridade; América Latina.

\begin{abstract}
This is a paper about dialogue. Its thesis is that Gadamer's hermeneutics doesn't fit the philosophy of liberation to think the dialogue in Latin America due to the metaphysics contrast of both theories. The German author dedicated himself to the subject and proposed the dialogue hermeneutics for western philosophy. The dialogue is a relationship of knowledge with the impersonal self of texts from the past (tradition), which is a metaphysical trace that the basis of dialogue of Gadamer's hermeneutics is not the same as that of Latin American philosophy. Therefore, the goal of this research is to review the concept of dialogue from the critical contribution of Dussel's philosophy. The methodology is divided into two parts: the first is a critique on dialogue in Gadamer's hermeneutics; the second deals with the perspective of dialogue inferred from Dussel's reflections on the concept of ethical conscience. The conclusion is that while the German hermeneutics proposes a dialogue based on the impersonal self of tradition, the philosophy of liberation suggests a dialogue whose foundation is our flesh faces transformed into a mask by the Eurocentric colonialism of power, knowledge and being. The ethical implication is that dialogue means liberating Latin American's alterity.
\end{abstract}

KEYWORDS: Dialogue; Being; Liberation; Alterity; Latin America.

\footnotetext{
${ }^{1}$ Mestre em Filosofia Social e Política na Universidade do Vale do Rio dos Sinos (UNISINOS). Professor de Filosofia no Grupo Pré-Vestibular FAJE (GRUFAJE). E-mail: renatoamdg@ protonmail.com.
} 
Este texto nasceu da intuição de que bases filosóficas eurocêntricas podem influenciar conceitos usuais em outras culturas. Embora o conceito de diálogo seja mundialmente utilizado, cada cultura atribui seu fundamento filosófico. O caso analisado é o diálogo na filosofia alemã, em contraste com o diálogo na filosofia latino-americana.

A nossa tese é que a hermenêutica de Gadamer, na obra Verdade e Método: traços fundamentais de uma hermenêutica filosófica, não serve para a filosofia latino-americana pensar o conceito de diálogo no hemisfério Sul, devido ao contraste metafísico de ambas. Enquanto o fundamento do diálogo, na hermenêutica alemã, é o Ser, desdobrado no tu impessoal de textos do passado, no livro de Dussel, intitulado Filosofia na América Latina: filosofia da libertação, é o rosto de carne e de osso que interpela a relação ética.

A novidade desta pesquisa está costurada na metodologia que segue com duas seções e a conclusão geral. A primeira é uma crítica à hermenêutica de Gadamer. O objetivo é mostrar que o filósofo alemão propõe uma visão de diálogo que não serve ao pensamento latinoamericano. Sua proposta é um pacto não rompido com a tradição do Ser. A segunda seção garimpa reflexões de Dussel sobre o conceito de consciência ética, as quais resultam numa proposta de diálogo como práxis libertadora: libertar o rosto latino-americano da máscara imposta pela colonialidade do poder, do saber e do ser. O texto conclui com desafios éticos do diálogo, concebidos como exercícios de filosofia da libertação e decolonial.

\section{A Hermenêutica do diálogo em Gadamer: um pacto não rompido com a tradição do Ser}

A hermenêutica de Gadamer não serve de base para a hermenêutica latino-americana, por dois motivos: 1) o diálogo não parte da alteridade de um tu de carne e osso, mas de um tu impessoal de textos do passado (a tradição); e 2) esse tu impessoal da tradição é um vestígio de que o diálogo, na hermenêutica de Gadamer, foi colonizado pela impessoalidade do Ser, da ontologia de Heidegger.

O diálogo situa-se no contexto epistêmico da crítica de Gadamer ao fechamento da ciência histórica na visão objetiva da tradição. Trata-se de uma herança do Iluminismo (Aufklärung) que usa a razão para evitar erros de juízo, desprezando os preconceitos:

A ciência histórica do século XIX é o seu mais soberbo fruto, e se entende a si mesma como a consumação do Aufklärung, como o último passo na liberação do espírito dos grilhões dogmáticos, como o passo rumo ao conhecimento objetivo do mundo histórico, capaz de igualar em dignidade o conhecimento da natureza da ciência moderna (GADAMER, 1999, p. 414). 
O Aufklärung condenou duas espécies de preconceito, a precipitação e a autoridade. Gadamer explicita a crítica do iluminismo à tradição: "A precipitação é a verdadeira fonte de equívocos que induz ao erro no uso da própria razão. A autoridade, pelo contrário, é a culpada de que nós não façamos uso da própria razão" (GADAMER, 1999, p. 416). A consequência é que a razão é elevada a senhora dos juízos, e os preconceitos são submetidos a ela.

Após essa crítica, Gadamer (1999, p. 414) propõe a "hermenêutica histórica". É a consciência "[...] adequada da finitude, que domina não apenas o nosso ser-homens, mas também nossa consciência histórica" (GADAMER, 1999, p. 415). Isso implica que o autor entende o exercício da razão como processo finito, histórico: “a razão não é dona de si mesma, pois está sempre referida ao dado no qual se exerce" (GADAMER, 1999, p. 415). Apenas com a consciência de que a razão pertence à história, já que, antes de exercer a razão, o ser humano está na história (família, sociedade, Estado), pode-se superar o historicismo.

Gadamer (1999) concebe a hermenêutica histórica como um sistema finito e aberto de interpretação - hermenêutica da finitude -, já que, para o filósofo, história, socraticamente, é a consciência de não saber a respeito de um saber desconhecido. A hermenêutica da finitude é um projeto de superar o preconceito historicista contra a tradição.

O historicismo é ingênuo porque confia demais em seus procedimentos e não faz hermenêutica da própria historicidade (GADAMER, 1999). O autor percebe que quando opôs razão aos pré-conceitos, o Aufklärung atrelou autoridade à obediência cega. Destarte, Gadamer desvencilha o conceito de autoridade da obediência submissa. Autoridade, para ele, é reconhecer que o outro conhece mais, ou seja, que o outro é superior em juízos. E, nessa perspectiva, é que resgata a tradição como uma forma de autoridade. A tradição é o fundamento da validez dos costumes, e não inspiração arbitrária (GADAMER, 1999).

A visão cientificista da história reduziu a tradição ao velho, ao histórico, àquilo que não diz nada para o intérprete do presente, porque não o faz pensar por si mesmo. A proposta gadameriana é de um círculo hermenêutico capaz de reabilitar a tradição, a partir de três categorias: consciência da história efeitual, diálogo-dialético e fusão de horizontes.

Quanto à consciência histórica, Gadamer estabelece que ela é experiência hermenêutica de compreender o tu da tradição a partir dele mesmo: "Quem quer compreender um texto, em princípio, deve estar disposto a deixar que ele diga alguma coisa por si. Por isso, uma consciência formada hermeneuticamente tem que se mostrar receptiva, desde o princípio, para a alteridade do texto" (GADAMER, 1999, p. 405). Isso implica que a consciência da história efeitual não faz dos intérpretes senhores do passado, mas submissos à tradição. 
Trata-se de "[...] experimentar o tu realmente como um tu, isto é, não passar por alto sua pretensão e deixar-se falar algo por ele" (GADAMER, 1999, p. 532). A consciência da história efeitual resulta em deixar que a aproximação do intérprete da tradição converta-se em experiência dialogante com o tu dos textos interpretados.

Nesse sentido, o diálogo-dialético aparece como instrumento da hermenêutica gadameriana, herdada do Sócrates de Platão. Dialogar dialeticamente com o tu do pretérito é perguntar pela pergunta que a tradição faz e busca responder para seu tempo. Quando se entra em relação com os textos do passado, por meio do diálogo hermenêutico, estabelece-se uma relação vital com a tradição da qual não se pode sair reflexivamente. Para Gadamer, a saída dessa relação vital seria destruir “[...] o verdadeiro sentido dela” (GADAMER, 1999, p. 532).

Se existe uma saída da tradição é aquela em que o intérprete sai alterado por ela. Gadamer, indagando sobre o diálogo, afirma:

\footnotetext{
Um diálogo é, para nós, aquilo que deixou uma marca. O que perfaz um verdadeiro diálogo não é termos experimentado algo de novo, mas termos encontrado no outro algo que ainda não havíamos encontrado em nossa própria experiência de mundo. $\mathrm{O}$ diálogo possui uma força transformadora. Onde o diálogo teve êxito ficou algo para nós e em nós que nos transformou (GADAMER, 1999, p. 247).
}

Nesse trecho, o filósofo descobre que o sentido do diálogo com a tradição é uma atividade que produz transformação em seus leitores e intérpretes. A hermenêutica pressupõe que o exercício ético do pensamento modifica o modo de ser e de viver de quem pratica o diálogo com os textos do passado. Ler é transformar-se pelo lido.

Gadamer (1999, p. 533) observa que o diálogo hermenêutico é a "disposição à experiência". Não se trata de apenas reconhecer a alteridade do que passou, mas de deixar que o tu da tradição diga suas próprias palavras (GADAMER, 1999), ou seja, dispor-se à experiência da relação de escuta das pretensões de verdade dos textos lidos. Essa tradição é linguagem, pois "fala por si mesma" (GADAMER, 1999, p. 528).

O diálogo hermenêutico nunca é uma situação mecânica, controlada e precisa, é linguagem. Acontece pela disposição afetiva do eu que interpreta, e aciona nele sentimentos, emoções, valores. E sempre escapa algo do eu da tradição que pode surpreender mais tarde o leitor. E é isso que faz do diálogo um desafio essencialmente linguístico de alteridade, mas com o tu impessoal da tradição.

O diálogo-dialético possibilita que o próprio tu da tradição protagonize uma fusão de horizontes. O horizonte histórico do leitor se funde com o horizonte dos textos que lê e, assim, mantém a abertura de interpretação, que permite ao hermeneuta voltar sempre à tradição pelo 
método da pergunta e resposta, para obter as razões que procura. Gadamer entrevê que a essência da hermenêutica é a experiência da historicidade que leva o intérprete a formular perguntas e esperar respostas da tradição (GADAMER, 1999).

Até aqui, analisamos as evidências do primeiro motivo que impede de a hermenêutica do diálogo, de Gadamer, servir para a hermenêutica latino-americana. Ou seja, ela não parte da alteridade de um tu de carne e de osso, mas de um tu impessoal do conhecimento da tradição. Resta-nos, agora, examinar o segundo motivo, que consiste em o tu impessoal da tradição ser um vestígio de que o diálogo, na hermenêutica gadameriana, foi colonizado pela impessoalidade do Ser, da ontologia de Heidegger.

É sabido que os hermeneutas buscam evidências de que há tanto continuidades quanto descontinuidades de Gadamer com Heidegger. Ernildo Stein pensa que a hermenêutica de Gadamer busca evidenciar o que está além das determinações da existência humana:

\begin{abstract}
E este além não é simplesmente o processo cultural histórico, etc., mas é exatamente isto: de, pelo fato de a verdade ter esse caráter histórico e estar ligada à história do ser, não é inteiramente exprimível na idéia da compreensão do ser e de que algo determina essa compreensão do ser e nos limita. Nesse sentido, a verdade é apresentada como verdade finita, não apenas enquanto ligada ao Dasein, mas enquanto o Dasein é o lugar de emergência da história do Ser que limita a compreensão do Ser (STEIN, 1993, p. 29).
\end{abstract}

Gadamer parece que não rompe com o Ser, que opera no tempo do ser humano, o qual busca compreender o sentido de sua existência na história do próprio Ser. O Dasein é a existência humana como intérprete das manifestações do Ser no tempo. O homem, como ser de compreensão, é o Ser-aí (Dasein) histórico, cujo tempo é regido pelas possibilidades do Ser.

Kusch explicita seu acordo com Stein quando afirma:

[...] a historicidade dos seres humanos consiste em que eles não são nada mais do que um elemento sem poder no curso da história [de modo que, assim,] analogamente à noção heideggeriana do Ser como determinante da condição humana, os seres humanos são ocasionalmente caracterizados por Gadamer como estando sob a tutela da história (KUSCH, 2001, p. 256).

Se o Ser se temporaliza, e a história é a compreensão registrada do Dasein sobre as manifestações do Ser, logo, na hermenêutica de Gadamer, o próprio Ser é a condição transcendental da relação dialógica do intérprete com a tradição. O intérprete dialoga com a impessoalidade do Ser no passado. O Dasein é o intérprete serviçal do Ser impessoal no tempo.

Infere-se que o Dasein do passado, aquele que interpretou o Ser em sua época, é o tu impessoal da tradição, como afirma Hintikka (2000, p. 492): “o que Gadamer está nos dizendo pode ser dito assim: Dasein está vivo e bem sob a roupagem da nossa tradição”. 
O Ser de Heidegger está pressuposto em Gadamer, como conceito de horizonte:

O conceito de horizonte se torna aqui interessante, porque expressa essa visão superior mais ampla, que aquele que compreende deve ter. Ganhar um horizonte quer dizer sempre aprender a ver mais além do próximo e do muito próximo, não para apartá-lo da vista, senão que precisamente para vê-lo melhor, integrando-o em um todo maior e em padrões mais corretos (GADAMER, 1999, p. 456).

A relação dialógica do intérprete com a tradição ocorre no horizonte do Ser, porque interpretar o passado não é só possuí-lo no conceito, mas deixar que o tu impessoal da tradição fale por si. Kusch constata que, em Gadamer, está "o círculo hermenêutico implicado no Serno-mundo do Dasein (KUSCH, 2001, p. 263). Na verdade, o tu da tradição é a transcrição temporal do Ser impessoal, cuja manifestação o Dasein interpretou.

Ao tratar de fusão de horizontes, Kusch afirma que, em Gadamer

[...] parece ser que a fusão de horizontes, longe de ser de autoria do intérprete, é obra da tradição ou, mais especificamente, da linguagem [...] aqui, naturalmente, somos lembrados das afirmações de Heidegger de que a linguagem fala por nós e que nós deveríamos aceitá-la como nossa mestra (KUSCH, 2001, p. 256-257).

Dutt corrobora que, em entrevista, Gadamer exprimiu sua afeição ao Ser, quando comentou a Carta ao Humanismo, de Heidegger: "me segue parecendo verdade [...] que a linguagem não é só a casa do ser, mas também a casa do homem, na qual vive, se encontra com outros, se encontra com o outro" (DUTT, 1998, p. 58). Quando estabeleceu que a casa do Ser é a linguagem, Heidegger dissolveu o humano no Ser, ou seja, tornou o sujeito impessoal.

Ao concordar com Heidegger, Gadamer não rompeu com a tradição do Ser. Aliás, fez um pacto permanente, ao levar o sujeito para conviver com o Ser no mesmo lar: a linguagem. Nesta casa, continua vigorando o paradoxo de que o ser humano é, ao mesmo tempo, pastor (cuida) do Ser e rebanho obediente ao Ser, em sua relação dialógica com o tu da tradição. Por isso, a implicação fundamental é que Gadamer desloca o termo alteridade da pessoa de carne e osso para a impessoalidade do Ser expressa no tu da tradição.

O Ser é a ontologia de um povo (europeu) que, na história, se impôs como centro do mundo. E, desde esse lugar, a impessoalidade do Ser é a experiência de superioridade europeia sobre os povos não-europeus, a qual a filosofia alemã soube conceituar. Essa superioridade opera, pois, pela colonialidade do poder, do saber e do ser.

Na história da colonização europeia, não há diálogo, porque a metrópole encobriu a alteridade das colônias por meio da colonialidade operante no exercício do poder, na produção do saber e na hierarquização do ser do conquistador em relação ao conquistado. Há somente imposição de monólogo, porque, na colonialidade, a voz que predomina é a de quem domina. 
$\mathrm{Na}$ história do poder operante nas colônias europeias, o colonialismo precede a colonialidade, pois "Colonialismo denota una relación política y económica, en la cual la soberanía de un pueblo reside en el poder de otro pueblo o nación, lo que constituye a tal nación en un imperio" (TORRES, 2007, p. 135).

O colonialismo é o primeiro modelo de poder exercido pelos impérios europeus no alvorecer da modernidade. Estabelece uma relação política de tipo imperialista, centrada na expansão do domínio territorial europeu pela conquista de outros povos. A América Latina, por exemplo, foi, predominantemente, colonizada pelos ibéricos: os espanhóis e portugueses.

Associada à conquista imperialista está a relação econômica mercantilista com os dominados. O mercantilismo é a primeira versão moderna do capitalismo mundial, eurocentrado e colonial. Sua lógica gira em torno do eixo trabalho-capital (TORRES, 2007), para explorar os recursos e controlar a produção de riquezas dos territórios conquistados. $\mathrm{O}$ trabalho é a mão-de-obra escrava do africano e servil do indígena, o qual convertia os recursos naturais em capital para a Metrópole.

A tese de Dussel é que os europeus (o centro) dominaram povos não-europeus (periferia) por duas lógicas de poder. A primeira são as "injustas, cruéis, sangrentas e tirânicas guerras" (DUSSEL, 1977, p. 15), que resultam na morte do outro. A segunda é a "dura, horrível e áspera servidão" (DUSSEL, 1977, p. 15) dos índios e africanos, cujo desfecho é a sujeição cultural dos povos conquistados aos conquistadores. A origem da grande riqueza e acumulação primeira do capitalismo que agora nos oprime é "o ouro dos índios e as carnes dos escravos negros" (DUSSEL, 1977, p. 63).

O poder imperialista não termina na colonização imperial. Ele permanece no tempo como colonialidade do poder capitalista:

[...] la colonialidad se refiere a un patrón de poder que emergió como resultado del colonialismo moderno, pero que en vez de estar limitado a una relación formal de poder entre dos pueblos o naciones, más bien se refiere a la forma como el trabajo, el conocimiento, la autoridad y las relaciones intersubjetivas se articulan entre sí, a través del mercado capitalista mundial y de la idea de raza (TORRES, 2007, p. 135).

A colonialidade surge quando aparece a classificação social que distingue a identidade do europeu colonizador das identidades colonizadas. Quando o branco nomeia os sujeitos conquistados como índio, negro e mestiço. Esse mecanismo de classificar se funda na ideia de raça, em que vigora a relação de sujeição dos colonizados aos colonizadores pela cor da pele. A identidade europeia denota superioridade sobre as identidades não-europeias. 
A colonialidade do poder é a imposição capitalista de uma "classificação racial da população mundial" (QUIJANO, 2007, p. 95). Essa classificação opera nas dimensões materiais e subjetivas, através de "relaciones sociales de explotación/dominación/conflito" (QUIJANO, 2007, p. 98). O conceito de raça funda a relação de centro-periferia, como geografia de dominação política, econômica e cultural maximizada no mundo.

O exercício do poder na América Latina se constitui da imposição da ideologia de raça, sobretudo nos países do Cone Sul (Argentina, Chile e Uruguai). Os europeus idealizaram a hegemonia cultural da branquitude. $\mathrm{O}$ método foi a guerra declarada às etnias, por meio do genocídio físico e cultural da população nativa, negra e mestiça (QUIJANO, 2005).

A colonialidade não se exerceu somente como poder, radicado na classificação de raça, mas também como superioridade epistêmica do saber colonizador. A colonialidade do saber é o modo dualista como opera a visão etnocêntrica e eurocêntrica no mundo. Converte os povos não-europeus em “domináveis e exploráveis” (QUIJANO, 2005, p. 133), por meio do critério da raça associado à cognição. Do lado da razão europeia, estão os civilizados e modernos. Do lado da irracionalidade não-europeia, estão os primitivos e tradicionais.

O etnocentrismo do europeu baseia-se no dualismo instalado por Descartes, que apregoava um hiato entre alma e corpo. A alma equivale ao fundamento da subjetividade, a razão, que é expressa na grande fórmula metafísica do cogito ergo sum. $\mathrm{O}$ fundamento da existência do sujeito é a razão, a alma dotada de consciência. O corpo é apenas a sede dos instintos, das pulsões irracionais e, por isso, um obstáculo para o conhecimento que provém da alma. Logo, a parte que deve comandar é a alma. Instala-se a soberania da razão sobre o corpo.

$\mathrm{Na}$ ideia de raça, há o ideal de humanidade, cujo fundamento é o modelo cognitivo eurocentrado. Esse paradigma consiste no poder exercido pela oposição entre o ser racional e o ser irracional. O ideal de humanidade é a nação racional, moderna, o qual é um evolucionismo racista unidirecional e linear, cujo destino é a sociedade europeia. Os europeus consideravam-se o fim da história evolutiva das raças. Os não-europeus foram vistos como povos que perderam o metrô do progresso, por serem irracionais, sem alma, primitivos, em franco estado de natureza.

O ideal de subjetividade moderna é o ego conquiro, imposto pelo homem imperial, ao qual a formulação cartesiana do ego cogito reforçou (TORRES, 2007). Da combinação das duas fórmulas deduz-se outra: eu conquisto, porque eu penso. Eu penso, porque, na escala de humanização, eu tenho uma alma racional. O bárbaro (o não-europeu) agora torna-se uma identidade racializada pelo homem imperial, conquistador. 
Da dúvida metódica, chega-se ao fundamento da subjetividade do europeu moderno, a substância pensante. O ceticismo cartesiano é o método do europeu para provar que ele tem uma alma, ou que é um ser racional. É, pois, um ceticismo misantropo, em que o dominado é objeto de perguntas cínicas do dominador: “és na realidade racional?” (TORRES, 2007, p. 138).

A pergunta racial, por excelência, feita na colonização da América é: têm o índio e o negro uma alma? Ora, o dominador conclui: se são dominados, não a possuem. Se não pensam, são selvagens a serem domesticados. O homem imperial se viu representado nessa dúvida metódica que reforça a sua prática de dominação pelo ceticismo misantropo.

$\mathrm{Na}$ lógica da colonialidade do saber, o ego conquistador é res cogitans - subjetividade pensante. O ego conquistado é res extensa - matéria/corpo não-pensante (TORRES, 2007). Logo, a dominação racial equivale ao poder da alma pensante sobre o corpo do dominado, reduzido a matéria destituída de razão.

A tese de Dussel (1977) é que, nas universidades das colônias, por exemplo, no México e em Lima, reinava a filosofia do colonizador pela lógica da imitação. Os nativos apenas reproduziam a filosofia europeia, do eu domino pelo saber, e eu conquisto pelo poder econômico e político.

Os pesquisadores da época não eram mais do que "entes à disposição da 'vontade de poder' como vontades impotentes, dominadas. Mestres castrados que castram os seus discípulos" (DUSSEL, 1977, p. 18). Eles viam a si mesmos com os olhos do centro, pois interpretavam a periferia como não-ser e ensinavam aos seus discípulos que nada podiam ser (DUSSEL, 1977).

Os europeus, na filosofia, podem ser muitas possibilidades, porque o ser da ontologia europeia é uma reinvindicação permanente de poder sobre os conquistados. Quem é da periferia nada é, porque resta ou imitar o pensamento de seus conquistadores ou produzir subcultura filosófica. Por isso, o fundamento da colonialidade do saber é a ontologia do não-ser, atribuída pelo centro à periferia.

Se o nada epistemológico opera no saber do colonizado, a colonialidade do ser é um passo metodológico mais refinado do colonizador em relação ao colonizado. Foi preciso uma ontologia para aprofundar o dualismo cartesiano do eu conquistador e do eu conquistado, ou seja, radicalizar a distinção entre o centro e a periferia. Colonizar pelo Ser é naturalizar a periferia por meio da ontologia do dominador:

O pensamento que se refugia no centro termina por ser pensado como a única realidade. Fora de suas fronteiras está o não-ser, o nada, a barbárie, o sem-sentido. O ser é o próprio fundamento do sistema ou a totalidade de sentido da cultura e do mundo 
do homem do centro. A ontologia, o pensamento que exprime o ser - do sistema vigente e central -, é a ideologia das ideologias, é o fundamento das ideologias do império, do centro (DUSSEL, 1977, p. 11).

A periferia começa a existir na filosofia, quando o ser se instaura como a identidade metafísica daqueles que dominam, aqueles que são. Fora do Ser não existe realidade. Fora do centro, só há periferia, barbárie, atraso, irracionalidade, subcultura filosófica. Para Dussel (1977), a periferia exprime o não-ser porque o centro é. O centro forja a sua ontologia de maneira nietzscheanamente ressentida: afirma o valor do Ser, reduzindo a periferia ao nada.

A tese de Dussel é que a filosofia do Ser aniquila o outro. O ser é o horizonte em que se justifica a dominação de escravocratas sobre o estrangeiro, sobre os colonizados. Aristóteles já definira o escravo como naturalmente escravo. O sentido da ontologia clássica está em excluir o outro, aquele que não é grego, o estrangeiro. O ser é o grande muro que defende o pensamento dominante, a ideologia do centro imposta à periferia.

A colonialidade do ser é impor a transcendência humana através de uma ontologia do Ser, como a experiência de uma subjetividade conquistadora. Heidegger prendeu a transcendência do ser humano na experiência do Ser impessoal. Não se pode viver e pensar fora do Ser. Ele é o lugar onde a pluralidade da existência humana se reduz a viver na impessoalidade, que opera como possibilidades múltiplas de vir-a-ser do ser humano.

Lévinas identifica que os filósofos do Ser "exaltam a obediência que nenhum rosto ordena" (LÉVINAS, 2015, p. 295). Uma obediência ao Ser como experiência de transcendência da vida humana, em que a impessoalidade toma o lugar do outro. A transcendência no ser hostiliza a alteridade, porque substitui o sujeito por uma racionalidade impessoal, como no trecho:

[...] (há) necessidade de libertar o Eu da situação em que, pouco a pouco, os filósofos o dissolveram de uma maneira tão total como o idealismo hegeliano, em que a razão engole o sujeito. A última filosofia de Heidegger torna-se um materialismo envergonhado. Põe a revelação do ser na habitação humana entre Céu e Terra, na expectativa dos deuses e em companhia dos homens e promove a paisagem ou a <<natureza-morta〉> a origem do humano. O ser do ente é um Logos que não é verbo de ninguém. Colocar o Neutro do ser acima do ente, que o ser determinaria de algum modo sem ele saber, colocar os acontecimentos essenciais com o desconhecimento dos entes - é professar o materialismo. O materialismo não está na descoberta da função primordial da sensibilidade, mas no primado do Neutro (LEVINAS, 2015, p. 295-296).

Para Heidegger, a ontologia clássica colocou Deus como fundamento do Ser e, portanto, a metafísica ocidental é uma ontoteologia. Ele identifica que só há uma existência para quem a pergunta pelo Ser faz sentido, o ser humano, denominado de Dasein (HEIDEGGER, 2012). 
O Ser foi esquecido pela metafísica clássica. Então, ele é reabilitado como Absoluto, pois nada existe fora do Ser, que é substantivado como a manifestação paradoxal nas entidades. Ora se mostra, ora se esconde nos entes. O Ser nunca é captado em sua totalidade, porque é sempre a possibilidade de vir a ser dos entes, que são nele e para ele, isto é, são apenas um receptáculo que abriga o Ser em seu poder infinito de manifestação. O Ser, por isso, exige do Dasein (Ser-aí) uma hermenêutica capaz de pastoreá-lo em suas possibilidades de se revelar. A existência humana é, assim, uma tarefa temporal de cuidar do Ser.

Na colonialidade do ser, a ontologia do Ser impessoal existe para não ser dominada, pois ele é soberano. Apenas o cuidamos para que seja da melhor forma possível em nós. E o modo do Ser operar é, de acordo com Lévinas, como Il y a (haver) (LÉVINAS, 2015). Ou seja, o Ser existe como uma razão universal que tenta fundar a existência humana na impessoalidade. Existir não é viver como rosto de carne e osso, mas ser na impessoalidade: há viventes, mas quem?

Na lógica do Il y a, a consciência apenas constata a existência dos fatos da vida humana, sem estabelecer proximidade com a alteridade de cada indivíduo. É somente uma relação de conhecimento, de definição universal, por isso, é impessoal, não quer proximidade com o rosto encarnado do outro. A existência na proximidade com o rosto de carne desaparece na transcendência do Ser da ontologia de Heidegger.

Se desaparece o rosto, o sujeito se dissolve no Ser. Na perspectiva da alteridade, há desejo de encontro, de proximidade, de querer responsabilizar-se pelo rosto que padece e interpela ao cuidado. $\mathrm{O}$ rosto que, na relação intersubjetiva, interpela com o mandamento: Não me mate! Não me escravize! Não me explore! Não me domine! Cuide de mim!

Quando a Alemanha se encontrava sob o rebaixamento do orgulho germânico, o líder do nazismo aparecia como a promessa de resgate da autenticidade individual e coletiva alemã (TORRES, 2007). Hitler é a liderança política que usa o poder com violência para recuperar o orgulho do ser dominador. O método da não-ética da guerra (TORRES, 2007) entra em ação e condena milhões de judeus ao holocausto nazista. Faz a limpeza étnica para preservar a raça pura.

A filosofia europeia, com raras exceções, encobre a ética da alteridade pela ontologia do Ser soberano. É a história da dominação do Ser sobre a diferença, o rosto do outro nãoeuropeu. A ontologia de Heidegger é a filosofia que legitima o poder de anulação do outro. Segundo Torres, ela é "cómplice de la violencia" (TORRES, 2007, p. 133). A filosofia da alteridade é a crítica à filosofia do Ser, um álibi do antissemitismo e do holocausto judeus.

A filosofia da libertação percebeu a relação entre a ontologia e o projeto colonial de dominação. A perspectiva da alteridade é a subversão da filosofia do Ser. Filosofar para libertar 
é a voz da ética que se levanta contra a voz da ontologia europeia, ancorada numa relação antidialógica, impessoal, violenta, porque reduz o rosto a objeto que serve ao Ser.

O lado colonial do Ser é que o rosto conquistado é vencido pelo Dasein conquistador. A colonialidade do ser aparece na crítica de Heidegger à fórmula de Descartes que privilegia a abordagem epistemológica e não ontológica da subjetividade humana. Heidegger substitui o “cogito ergo sum pelo penso, logo sou" (TORRES, 2007, p. 149).

A radicalização heideggeriana da fórmula cartesiana esconde uma relação de poder, centrada na diferença ontológica entre o ser e os entes, que se desdobra numa relação de uso do Dasein para com os entes. Essa instrumentalização aparece na diferença ontológica colonial, em que o rosto colonizado é convertido em instrumento pelo Dasein colonizador.

O ser colonial nega virtudes cognitivas aos sujeitos racializados (TORRES, 2007). Se não pensam como o colonizador, não são humanos, são selvagens, inferiores. A tese de Torres é que, a partir de Descartes, a dúvida sobre a humanidade dos colonizados se torna uma convicta falta de razão. A colonialidade do ser é a naturalização da não-ética da guerra na conduta do colonizador. É a violação corporal e a morte do distinto (TORRES, 2007).

Colonizar através do ser impessoal é a "violación del sentido de la alteridade humana, hasta el punto donde el alter-ego queda transformado en um sub-alter" (TORRES, 2007, p. 155). Ela produz sujeitos elimináveis. Transforma a subjetividade, que é rosto, um tu imanipulável, em subjetividade de sujeição, um tu subalterno, que gira em torno do eu conquistador. O ser expressa a diferença ontológica colonial, baseada na ideia de raça e de “ceticismo misantropo" (TORRES, 2007, p. 156).

Cria-se, pois, um devotamento subserviente à filosofia da impessoalidade do Ser, isto é, da negação do rosto de carne e sem identidade concreta. E a vida humana torna-se mera existência diluída na consciência e para a consciência eurocentrada. O Ser exerce soberania sobre a pluralidade do rosto, da alteridade de povos dominados e de culturas colonizadas.

Torres defende que a conquista da América Latina, da África e da Ásia totaliza o outro no mesmo, isto é, aliena-o de sua exterioridade. Isso implica retirá-lo de seu próprio centro para girar ao redor do centro alheio, do eu conquistador. A negação do outro é alienação. Alienar um povo é "fazer-lhe perder seu ser ao incorporá-lo como momento, aspecto ou instrumento do ser de outro" (TORRES, 2007, p. 58). A alienação do outro é a violência totalitária do dominador que impõe ao dominado a servidão do pensamento. 
Portanto, a dominação transforma o rosto de carne do distinto em instrumento, em coisa sem transcendência e sem mistério. Dussel percebe que o rosto é convertido em máscara que não interpela. A práxis de dominação é coagir o outro a ficar no sistema que o aliena.

O ethos dominador se realiza pelo costume o pelo temor de não sobreviver. Se o dominado subverte a ordem dominante, o dominador declara guerra. A guerra é a "ontologia prática" (DUSSEL, 1977, p. 60) da dominação, pois "é o ser que praticamente reduz o outro a não-ser" (DUSSEL, 1977, p. 61). O ódio ao outro é o sentimento que instala a guerra declarada ao inimigo: o distinto do eu conquisto. Nesse caso, a guerra imposta implica que, no exercício da colonialidade, a relação de dominação precede a relação de diálogo.

Na próxima seção, o objetivo é delinear a perspectiva de diálogo na filosofia latinoamericana, desde a reflexão de Dussel sobre a consciência ética. Daí, infere-se que o diálogo, na filosofia da libertação, não é relação com o tu impessoal da tradição, mas relação ética entre rostos de carne e osso que interpelam-se mutuamente e, como tais, são alteridade.

\section{Diálogo em Dussel: libertar o rosto da máscara fabricada pela colonialidade}

Dussel vai além da hermenêutica do diálogo de Gadamer, restrita à boa consciência moral na relação de conhecimento com o tu impessoal da tradição. O filósofo latino-americano supera essa lógica com o fundamento do diálogo, que é o rosto de carne e osso. A filosofia latino-americana é, essencialmente, uma ética da libertação dos oprimidos. Nela, o diálogo é consciência ética que põe em questão os valores do sistema dominante, como se vê:

Chamamos consciência ética a capacidade que se tem de escutar a voz do outro, palavra transontológica que irrompe de além do sistema vigente. Somente quem tem consciência ética pode aceitar o questionamento a partir do critério absoluto: o outro como outro na justiça (DUSSEL, 1977, p. 65).

O diálogo como consciência ética exige condições de possibilidade para ouvir a voz do outro. A primeira condição é sermos "ateus do sistema ou descobrir seu fetichismo" (DUSSEL, 1977, p. 65). É ser cético com relação à tradição que pode reforçar a dominação do rosto de carne. A segunda condição é "respeitar o outro como outro" (DUSSEL, 1977, p. 66).

O respeito é a posição de passividade ética, de reverência ao rosto, de deixá-lo "ser o que é como distinto" (DUSSEL, 1977, p. 65). Respeitar é o primado da liberdade do outro, como centro de seu próprio universo. E o outro não é mera categoria metafísica, é, em sentido ético, um rosto com carne que tem identidade, cor, sexo, corpo, etnia, lugar. 
O diálogo como consciência ética é responder pelo outro. A responsabilidade, não é demandar uma pergunta, mas é responder por uma pessoa. É "encarregar-se do pobre" (DUSSEL, 1977, p. 66). O pobre são os sujeitos não reconhecidos como centro de seu próprio mundo porque vivem sob o regime de dominação e de exclusão social. É ser para ele hospitalidade, acolhida. Dussel enfatiza que:

\begin{abstract}
Aquele que ouve o lamento e o protesto do outro é comovido na própria centralidade do mundo: é descentrado. O grito de dor daquele que não podemos ver significa para alguém mais do que algo. $\mathrm{O}$ alguém significado por seu significante: o grito nos exorta, exige que assumamos sua dor, a causa de seu grito. $\mathrm{O}$ 'tomar sobre si' é fazerse responsável (DUSSEL, 1977, p. 65-66).
\end{abstract}

O encontro com o rosto de carne nos interpela a tomar uma atitude de sensibilidade, de suscetibilidade à necessidade do outro, de não ser-lhe indiferente, mas próximo. $\mathrm{O}$ sentido do ser é algo que se domina por uma atitude de compreensão e definição totalizante.

A libertação não se faz apenas pela negação da opressão. É preciso afirmar o rosto do outro, a sua exterioridade. Trata-se de ir além da negação do sistema opressivo e de afirmar "a exterioridade do rosto no sistema" (ROSA, 2011, p. 139-140). O diálogo latino-americano só é possível à medida que se supera a diferença colonial dominador-dominado pela afirmação da alteridade do colonizado.

A consciência ética é um ato de amor ao rosto de carne dos povos em situação de vulnerabilidade. É ato de religar o outro com sua alteridade, com sua exterioridade, com seu além do sistema, por meio da solidariedade que expõe pessoas justas aos ataques do sistema (DUSSEL, 1977). Dialogar é responsabilizar-se pelo rosto oprimido sujeito à violência implacável da totalização sistêmica. Trata-se de ameaçá-la com o novo, com uma ordem ética subversiva.

Uma tese inovadora, em Dussel, é que a libertação da colonialidade do conquistador implica em a máscara tornar-se rosto. A máscara é a alienação produzida pelo sistema. Alienar é mascarar, ou seja, é encobrir o rosto do outro e tornar seu clamor inaudível. É definir o rosto pelo papel de instrumento que desempenha no sistema econômico: empregado, operário, camponês, escravo (DUSSEL, 1977).

O diálogo é uma práxis libertadora. Libertar o outro é promover a responsabilidade pela libertação do "rosto que interpela à justiça" (DUSSEL, 1977, p. 68-69). É responder pelo outro que ultrapassa o sistema. O outro é "a exterioridade que está além da ordem estabelecida do poder" (DUSSEL, 1977, p. 67). Dialogar é libertar o rosto da colonialidade do poder e fazer emergir o apelo à misericórdia, à rebelião, à revolução ética do rosto embaçado. 
A libertação pelo diálogo é "anarchica (em grego: além do princípio)" (DUSSEL, 1977, p. 67) porque rompe com o sistema da colonialidade, que encobre a alteridade. A ação libertadora é um serviço dirigido ao outro e realizado na responsabilidade por ele. É ação que subverte o sistema de colonialidade que se desdobra no "fratricídio da nação irmã, do irmão classe, do outro como irmão próximo" (DUSSEL, 1977, p. 85).

Para Dussel, libertar corresponde a humanizar a maneira de gerir a vida econômica no Planeta a serviço de quem foi empobrecido pelo sistema: "Não há libertação sem economia e tecnologia humanizada, e sem partir de uma formação social histórica. É a atividade inovadora do uso dos instrumentos que se põem a serviço do pobre" (DUSSEL, 1977, p. 70). Libertar é conferir uma finalidade ética à economia e à técnica: servir ao outro colocado à margem.

Libertar pelo diálogo é ser contra a colonialidade do poder da injustiça política que oprime "a mulher, o índio, o negro, o mestiço, a criança, o jovem, o idoso" (DUSSEL, 1977, p. 69). Na práxis de libertação, o processo libertário é "crítica real do sistema; é ruptura; é destruição" (DUSSEL, 1977, p. 72). É a negação da negação, ou seja, é “demolir a negação do outro" (DUSSEL, 1977, p. 73) na colonialidade do poder, do saber e do Ser.

O ethos da libertação dialogante é o hábito de instaurar o novo, de não reproduzir a mesmidade do dominador, o Ser, na América Latina. A estrutura metafísica desse ethos é "a comiseração, como capacidade alterativa para estar junto do outro com sua miséria” (DUSSEL, 1977, p. 70). Comiserar-se é ceder ao clamor por viver do rosto oprimido.

O fundamento ético da comiseração, para Dussel, é o contrário da violência do não-ser:

[...] é o amor ao outro como outro, como exterioridade; amor ao oprimido, mas não em sua situação de oprimido, e sim como sujeito da exterioridade (somente a isso chamaríamos miséria: a traumática posição do livre, do outro, da pessoa, que foi reduzida a um instrumento no sistema). Não é a amizade, nem a fraternidade (dos iguais), mas o amor aos oprimidos em razão de sua real dignidade como exterioridade (DUSSEL, 1977, p. 70).

Por isso, o diálogo, como libertação da colonialidade do Ser, exige substituir a lógica ontológica do impessoal, tida como experiência originária do ser humano, pela ordem ética da proximidade, que é nascer de um quem e em alguém. "Nasce do útero materno e é recebido nos braços da cultura" (DUSSEL, 1977, p. 24). O ser humano "alimenta-se de alguém, e não de algo" (DUSSEL, 1977, p. 24). Ou seja, o que funda a ética do diálogo é a proximidade, isto é, a acolhida no ventre materno de um ser indefeso que antecede a existência humana no mundo. A proximidade do rosto vulnerável precede a impessoalidade do Ser soberano.

A proximidade, assim como a da mãe e do filho, é a experiência originária da vida ética. O originário da vida humana é existir na proximidade entre um $e u$ e um $t u$, como face-a-face. 
Antes do Ser que guarda o sentido de existir, está a realidade do outro que se aproxima e interpela: Cuide de mim! A experiência originária da existência humanizada "é a responsabilidade pelo fraco, por aquele que precisa de cuidado" (DUSSEL, 1977, p. 25). Dialogar é uma forma de vida, é viver desde a experiência originária de ser próximo do outro.

O outro tem um rosto de carne que brada à beira do caminho: Estou com fome! O outro é um rosto interpelante de um povo - índio, negro escravizado, mestiço, mulher, jovem - pobre e oprimido. A revelação do rosto do pobre que sofre convida à justiça, questiona o sistema e, por isso, o outro é inimigo do sistema de injustiça, é a utopia da libertação (DUSSEL, 1977).

O outro é exterioridade, é um rosto livre, “é centro de seu próprio mundo" (DUSSEL, 1977, p. 51). O outro fala a partir de si, revela sua alteridade imanipulável pela razão ou por qualquer hermenêutica. O outro não fala pela compulsão do diálogo, para obter consenso ou para ser objeto de interpretação que compreende, a fim de instaurar sentido no horizonte do Ser.

O diálogo é libertação da colonialidade do Ser e subversão metafísica da ontologia fenomênica do logos sobre o ente que aparece desde o Ser. É fazer a passagem do Ser para o além do ser, a Alteridade. É reconhecimento do outro "que se revela em seu mistério de presença que se doa e que acolhe" (DUSSEL, 1977, p. 64).

O diálogo é viver na presença de um rosto que interpela ao reconhecimento de si como distinto, como fora do sistema da colonialidade. Dialogar é mais que estar em diálogo, é ser relação de diálogo, reconhecendo que diante de um tu há um outro que interpela ao cuidado.

O encobrimento da alteridade oculta a relação ética de "donación y receptividad del sujeto al Outro" (TORRES, 2007, p. 158). Quando o conquistado é dispensável, gênero, raça, sexo, corpo, servem como instrumentos de transgressão da relação ética de proximidade entre o eu e o outro (TORRES, 2007).

A libertação do ser através da consciência ética é "recuperar a subjetividade como 'alter-ego" (TORRES, 2007, 156-157). Trata-se de libertar a alteridade do conquistado encoberta pela colonialidade do conquistador. Ou seja, dialogar é descolonizar a subjetividade dos dominados, fundamentalmente é doação generosa e hospitalidade entre sujeitos. A colonialidade do ser transformou o rosto conquistado em sub-alteridade. Dialogar é libertar-se do Ser, para romper com "a guerra ao outro" (TORRES, 2007, p. 161).

O diálogo opera como oposição constante ao paradigma da não-ética da guerra do conquistador contra os povos dominados. Trata-se de uma ética da não-guerra, fundamentada na “doação, generosidade humana e responsabilidade" (TORRES, 2007, p. 10). É a ética que rompe com a lógica ontológica de sub-alteridade. 
O sub-alter representa sujeitos subalternos nas relações de saber, gênero, étnico-raciais, políticas, econômicas. É o oprimido que tem um rosto de carne padecendo injustiças. São os índios, os negros, as juventudes, as crianças, os idosos, as mulheres, os LGBTs. Libertar pelo diálogo é uma forma de vida ética que opta pelos povos e indivíduos injustiçados.

\section{Conclusão}

À guisa de conclusão, vimos que Gadamer propõe um diálogo, com base no tu impessoal de textos do passado (tradição). A filosofia de Dussel sugere uma perspectiva de diálogo cujo fundamento é o rosto de carne, transformado em máscara pela colonialidade do poder capitalista, do saber cético de Descartes e do Ser impessoal de Heidegger.

Se o fundamento ético do diálogo é o rosto de carne, dialogar é uma forma de vida agônica, ou mesmo uma filosofia decolonial, cujo exercício ético é crítico, pois busca a libertação da alteridade encoberta pela colonialidade, o que implica três desafios: 1) relação ética de proximidade responsável do rosto de carne e osso; 2) opção ética, política, social e epistêmica pelo rosto oprimido; 3) descolonização transdisciplinar da alteridade encoberta.

O primeiro desafio pressupõe que a consciência ética precede a consciência epistêmica, pois a proximidade do tu de carne e osso indefeso é anterior à proximidade do tu impessoal e soberano da tradição. O diálogo é, antes, uma relação ética com o rosto concreto de quem padece os efeitos da colonialidade do poder capitalista, do saber eurocêntrico e do ser impessoal da hermenêutica europeia.

No segundo desafio, o pressuposto é que a opção ética, epistêmica, política, social pelo rosto oprimido da América Latina é condição para libertar a alteridade latino-americana encoberta pela racionalidade colonial. Dialogar é escutar o sofrimento e a opressão do rosto de carne e osso que, em si, são o clamor histórico da alteridade latino-americana por libertação da lógica de encobrimento colonial do poder capitalista, do saber etnocêntrico e do ser impessoal.

O terceiro desafio pressupõe que a libertação das formas de colonialidade, já mencionadas, requer solidariedade epistêmica entre epistemologias - indígenas, afro-americanas - do hemisfério Sul. Exige abandonar o modo colonial, do conquistador, de construir conhecimento para assumir uma maneira ética de produzi-lo. Trata-se de passar de um trabalho epistêmico individualista para a construção coletiva de pensamento crítico e de saber que liberta. 


\section{REFERÊNCIAS BIBLIOGRÁFICAS}

DUSSEL, E. Filosofia na América Latina: filosofia da libertação. Tradução de Luiz João Gaio. São Paulo: Loyola, 1977.

DUTT, C. En conversación con Hans-Georg Gadamer. Presentación y traducción de Teresa Rocha Barco. Madrid: Tecnos, 1998.

GADAMER, H.-G. Verdade e Método: traços fundamentais de uma hermenêutica filosófica. Tradução de Flávio Paulo Meurer. Petrópolis: Vozes, 1999.

HEIDEGGER, M. Ser e tempo. Tradução de Fausto Castilho. Campinas: Unicamp; Petrópolis: Vozes, 2012.

HINTIKKA, J. "Gadamer: squaring the hermeneutical circle". Revue Internationale de Philosophie, Bruxelles, v. 54, n. 213, p. 487-497, 2000.

KUSCH, M. Linguagem como cálculo versus linguagem como meio universal. São Leopoldo: Ed. Unisinos, 2001.

LEVINAS, E. Totalidade e Infinito. Tradução de José Pinto. Lisboa: Edições 70, 2015.

QUIJANO, A. Colonialidade del poder y clasificació social. In: CASTRO-GÓMEZ, S.;

GROSFOGUEL, R. (Ed.). El giro decolonial: reflexiones para una diversidad epistémica más allá del capitalismo global. Bogotá: Siglo del Hombre Editores, 2007. p. 93-130.

QUIJANO, A. Colonialidade do poder, eurocentrismo e América Latina. Buenos Aires: CLACSO, 2005.

ROSA, L. C. D. A alteridade e a relação pedagógica no pensamento de Henrique Dussel. Diálogo, Canoas, RS, n. 19, p. 131-144, 2011.

STEIN, E. Seminário sobre a verdade: lições preliminares sobre o artigo 44 de Sein und Zeit. Petrópolis: Vozes, 1993.

TORRES, N. M. Sobre la colonialidad del ser: contribuciones al desarrollo de un concepto. In: CASTRO-GÓMEZ, S.; GROSFOGUEL, R. (Ed.). El giro decolonial: reflexiones para una diversidad epistémica más allá del capitalismo global. Bogotá: Siglo del Hombre Editores, 2007. p. 127-173. 